\title{
SCIENCE AND POETRY
}

Emotionality and rationality or differences and consensus regarding the basic units of the semantic plan of art and science. Relationship of the language and extra-linguistic area in scientific knowledge and poetry. Particularities of the poetic language and the language of science. Image and abstraction: a different ability of our spirit to reflect the world. The presence of metaphors in philosophy and natural sciences as a transcendence of common experience. Interactive understanding of metaphor and its pitfalls. Is metaphor usable in science and does it have a cognitive function?

Keywords: poetry, science, language, metaphor

\section{Introduction}

"If any man wish to write in a clear style, let him be first clear in his thoughts; and if any would write in a noble style, let him first possess a noble soul.“

Johann Wolfgang von Goethe

The American writer and philosopher Ralph Waldo Emerson, who called himself an "endless searcher without any past", once declared that scientists - botanists "love not the flower they pluck, and know it not. And all their botany is Latin names." He wanted to suggest that emotional approaches (e.g. love for the subject of the research) are often suppressed or denied by rational arguments in scientific practice. The perception of the emotional element in the poetic text and rational one in the scientific text is a primordial acceptance of the difference between the two types of reflection of the reality.

As we rarely seek rationality in poetic texts, we almost always avoid searching for emotionality in scientific texts. We denounce it, reject it, and even condemn it. But if we want to know what connects and what distinguishes the language of science from poetry, we also have to analyze the relationship between the linguistic and extra-linguistic area in scientific research and poetry. The majority of scientists are not able to express their thoughts as elegantly and suggestively as writers, but this disadvantage can be compensated by a deeper probe into knowing the subject of their interest, but also the results of the work of other scientists and of their own.

\section{Language of poetry and language of science}

Poetic language and language of science have their specifics, including in the first instance the ability to express the verse in verses and, on the other hand, the ability to abstract in a scientific work. Image and abstraction represent, from this perspective, various dispositions of our spirit to reflect the world and to mediate this reflection by others. "It is impossible to know everything!” This well-known idea from Goethe's Faust suggests the limitations of scientific knowledge. Hans Selye added also this sympathetic sentence: "Happy and naive is a scientist who has never experienced the cruel feeling of malice induced by this idea. ... Nature is eternal and infinite, but a man encounters it only in a small period of her life and measures its strength only with its limited ability. Brevity and simplicity are therefore not only random attributes of science: they are its basic, characteristic features" [1, p. 185].

It takes away the desire of mankind for leadership; it is a desire for knowledge of the truth ... But how can we distinguish the truth in science and poetry? This is related to the problem of interpreting science [2] and research results and, on the other hand, interpreting an artwork. What do these interpretations have in common and what distinguishes them?

Unlike the "reference" to science, in which the language unit should be clearly and precisely readable in specific contexts of extra-linguistic reality in the text, poetry seems to be objectively ineffective. Poetry is attributed to the extraordinary special values of "emotional language". The crucial criterion of truth

\footnotetext{
* Dalimir Hajko

Department of Philosophy and Religious Studies, University of Zilina, Slovakia

E-mail: dalimir.hajko@fhv.uniza.sk
} 
is, according to science, the independence of the "observer". This means that testimonies that are believed to be true must also be repeatedly perceptible. They must also be unconditional and completely uncompromising to the last detail. In poetry, we cannot talk about true and false statements; it actually contains logical "pseudo-years" [3, p. 11]. But they can also be true or false; their veracity lies in the inner coherence of the literary work and its psychological acceptability. Let us recall Nietzsche's claim that truth is born only in an active process of understanding...

But, looking at these vast areas of human activity, we will also discover a migration area, where both approaches to reality touch and overlap: it is a metaphorical area that we can encounter not only in poetry and art but also surprisingly in philosophy, or even in the natural sciences. The mere presence of metaphor not only in a poem that is considered to be extremely legitimate and directly desirable, but also in a philosophical work or occasionally in the interpretation of the natural sciences, means the unique realization of the possibility to transcend the common experience [4] and to create new bases for the non-standard and creative practices in our explanations of the natural and human world.

An interactional metaphorical understanding, despite all its pitfalls, gives us an opportunity to understand whether and to what extent the metaphor is usable in science and whether it can be used in its cognitive function. In broader sense of the word, it is the ability to incorporate elements of artistic perception into reality. It also leads to the courage to understand the unfamiliar context as well as to life, and the vision of discovering unrecognized relations between phenomena which are associated with it. The American historian and social critic Arthur M. Schlesinger Jr. (1917 - 2007) expressed a broad understanding: "If we are to survive, we must have ideas, vision, and courage. These things are rarely produced by committees. Everything that matters in our intellectual and moral life begins with an individual confronting his own mind and conscience in a room by himself" [5].

The same author asks whether there are any scientists at all who can say that they have never gained the power and beliefs from ideas that were born in other humans' minds. That they were never inspired and stimulated, for example, by the wisdom of Socrates, the fascinating works of Shakespeare and Dante, Luther's courage, Washington's determination, Napoleon's conquest and Lincoln's passion, and even Jesus' death. Notwithstanding the fact that none of these persons can be considered "scientific" in the traditional way. However, their contribution to history - and within them as well as to the history of world thinking - has, for various reasons, also the character of stimulant to scientific knowledge, a subtle inspiration of the scientific interpretation of reality, nature and man, the basis of analysis of the human spirit. Even in this sense, poetry and science, the poem as an artistic text and the scientific explanation of reality, are combined.

\section{3. "Literary" or "scientific" man}

Bachelard's so-called "literary man" concentrates on the meditative and expressive element of thought, in other words, thought and dream. He does not prove anything, but senses it and transfers his experience in an altered form. A "literary man" differs from the common idea we have about a so-called "human scientist". A "scientific man" schematizes a concrete fact into abstract lessons, and it can also be degraded from a certain point of view because he often does not define terms by terms that would need to be specified. The "rationalism of absolutist abstractions" should, according to Bachelard, lead to the construction of such a "supra-reality" that would surpass ordinary experience and show a new, non-traditional face of reality. It would complement "austere" scientific research.

A new example of a literary work on philosophical issues is the work of the American author Don DeLillo [6]. "Don DeLillo perceives Kierkegaard as more than mere moral authority, a spiritual brink. He is convinced that Kierkegaard's philosophy can give man hope even in the most difficult moments of life. At the time of one's personal apocalypse, experienced within the frame of reference of contemporary society that is permeated by modern technology, mass media and the omnipresent consumerism, which can but briefly satisfy the hedonistic needs and desires of the individual, Kierkegaard's philosophy can provide an impetus for a new life. DeLillo values Kierkegaard's thought, for it leads the reader into and through an existential crisis. It requires and, in some cases, induces a leap of faith, thus having the potential to become an inspiration or even an "existential path" for everyone seeking a way out of the hedonistic and aesthetic stages of life in order to achieve the ethical or even the religious dimension of one's life" [7, p. 19].

What is the relationship of such transcendence to reality? There can be no doubt that the so-called "overcoming" of ordinary rationalism means distancing and approaching reality at the same time. But even when we fall into the "subconscious of the scientific spirit", in the area of metaphors, naive beliefs, initial experiences, even then we transcend everydayness, custom. For example, in a literary work in which we encounter a city's image, "the interaction between the real city and text structures reflects the reader's consciousness, which allows the city to find beyond the boundaries of the city another city that is subject to his dreams, memories, or desires. This illusion of dejà vu, caused by the confusion of the text space and the city, at the same time, gave a new type of experience to the time that the literature attempted to amplify even in the area of the fictitious city" [8, p. 130].

This idea corresponds to Bachelard's phenomenology of a poetic image as developed in the works of Poetics of Space and Phenomenology of Fire, where, among other things, he examines the relationship between literature and science, transposed into the relationship between fantasy and rationality, a relationship that extends our knowledge beyond the limits 
of ordinariness. These phenomena may be conflicting but may also be complementary. The image can create strong emotional illusions inspiring science, but the same image can also produce unexpected effects in literature and especially in poetry. The poetic dream is "sympathizing" with reality, while the scientific approach is paradoxically "hostile" to reality in the sense that it is distancing itself from the emotional aspect of reality that it usually considers to be the burden of scientific inquiry.

Although metaphor has a different function in art and science, it is precisely the explanation of the poetic image that the metaphor of traditional understanding helps us to identify the essence of complex and little transparent relations between science and art, philosophy and poetry, scientific knowledge of reality, and its poetic images, between the different perceptions of the world. However, it must always be borne in mind that, as Richard Rorty said, "the world exists not only in a single way, so there is neither ... the only way of its adequate representation" [9, p. 120].

Johannes Pfeiffer, in his collection of essays entitled Between poetry and philosophy of 1947, has developed the view that poetry opens the hidden depths of existence and thus calls for a "justification" (Wessenhaftigkeit). Pfeiffer - and likewise other existentialist-minded authors - has adopted from Heidegger the term "tune" which, under the influence of a poetic work in us, rises and overcomes us. From this knowledge, it is no longer a matter of claiming that the scientist is permanently overcome by some "tuning" research, and that his creative enthusiasm is conditioned by an effort to overcome the "zero point" that defines the state of research. The understanding of the problem he solves then considers such a content understanding of the state of affairs, which consists not only of knowing something, but in connection with the intellectual empowerment of all contexts in which the state of affairs rests, including those which are not always reasonably acceptable. By understanding these writers, in the existentialist spirit, a return to the text has been strengthened, but criticism influenced by it tends to wipe out specific literary values and differences between poetry and philosophy, ultimately between poetry and science.

Charles Morris has already made it clear that it is a special kind of speech or a sign that defines "qualities that are values in fact or in possible situations; artistic work is an iconic image because it expresses values so that they can be captured directly" looking for qualities that are values in fact, poetry for those who become values in our dreams. But dream is also an element of reality. Dream cannot be totally rejected by science. For example, according to Bachelard there exists the physics and chemistry of dreaming, and he persuaded us that "metaphors are not ordinary idealizations that shoot like rockets to exaggerate their insignificance after the blast in heaven, but metaphors that call each other and coordinate more than feelings, so that the poetic spirit is pure and simple metaphor" [10, p. 143].
Metaphor is a bridge between the linguistic and the nonlinguistic area; it is a manifestation of subjective understanding of the relationship between the words and meaning network of their denotations; it is precisely in this relation that the presence of free associations is concentrated as an expression of the possibility of applying an intuitive component of scientific knowledge, which also includes extra-judicial moments. Thus, the metaphorical expressions of exact disciplines of science include the uniqueness, the unrepeatability of the situation in which the metaphor was created. This uniqueness, however, stands up to a clear translation into conceptual speech, but it is valuable in terms of overlapping of creativity and originality.

\section{The power of metaphor}

Metaphor is not only a means of visualizing and interpreting those objects of science that we cannot imagine directly but it is also a tool of knowledge that can have great heuristic value. Through the meanings, associations, and comparisons, metaphor allows imagination to associate even incompatible, seemingly foreign, distant phenomena. However, in the background, it does not lose sight of their difference, which is suppressed at first glance, but can be seen at higher level of generalization. According to Gadamer, hermeneutics is primarily an art of interpretation.

It is possible to divide in principle two levels in which a metaphor occurs and is used in scientific activities. The first plan is related to the genetic aspect of science, where the metaphor works best in the function of a laconic, short-lived hypothesis. The second plan is the stage of the already developed scientific theory in which metaphor certifies its participation as a conscious means determining the direction of the theoretical thinking in the transition from one area of knowledge to another. It reinforces the imaginativeness of expression in the meaning of such a quality of testimony, which expresses the overlap of the known or possible reality in apprehensions and images. "The interconnection of the farthest elements of reality in imagination is the basic principle of imaginativeness" [11, p. 191]. And imagination is a structuring element of scientific thinking.

Plesnik points out that the work of the main representatives of the interaction theory - I. A. Richards and M. Blake - overcomes the narrowed understanding of the metaphor typical of descriptive poetics. E.g. Richards does not understand the metaphor as a deviation from the common use of words, but as a picture of thinking that is based on comparisons and concepts. Therefore, according to him, words are not spoken in metaphors, but two different ideas combine into one active context. According to Lakoff and Johnson, metaphors already exist in the conceptual system of man.

Expression metaphors and metonymies have been reviewed by several deconstructionists: "J. Derrida dealt with the metaphor 
and its forms in the philosophical text; P. de Man has shown that language as a means of expression is not entirely reliable, as there are also processes such as those of the troppes, which in fact conquer the interconnection between the sign and the meaning ... The difference between one's own and the translated meaning of the words by which it seeks to understand the nature of the metaphor of traditional poetics is not important for the so-cognitive science (I know of the human mind). It is the metaphorical nature of our common conceptual system [11, pp. 190-191]

One of the issues that deserve much attention in this context is the question of how to interpret the results of science and research, and what the place of interpretation in science and research is at all, which differs from the scientific explanation from poetic understanding. Pronounced knowledge in leadership takes the form of interpersonal knowledge (as concepts and theories), while unspoken knowledge - works as personal knowledge. As a form of knowingly inaccurate description of true contexts, then the metaphor of the content access function fulfills the function that probabilistic ways of describing within the quantitative approach have.

The science metaphor problem is still up to date. Metaphor in scientific knowledge undeniably exists, but the problem remains its character and its relation to metaphors in art. In particular, the question is whether the ambiguous range and sometimes the alleged non-transferability of the metaphorical expression in the Vedic into a descriptive language without loss of the heuristic objective dimension do not show too much the nature of the artistic metaphor. This would mean knowing the use of the language of art in scientific language, the ability to learn in science from the study of artistic means. Although this possibility cannot be totally excluded, art theorists advocate rather the view of the specifics of artistic modes of expression that prevent them from doing so.

In principle, ideas that push scientific expression into pure abstraction and artistic expression into permanent imagery must be rejected. It is a dubious scheme, partly because science in its top theoretical positions cannot express itself differently than metaphorically, and because of its content expansion, it appeals to figurative language. In both cases, however, metaphority is rather in the sense of a clear "representation" of reality than in the sense of the "decay" of reality (the reflection of its interference disintegration). Important, and key, is the awareness of the relationship between tacit and explicit knowledge. We build the scientific picture of the world above all on explicit knowledge, that is, we can express in some formalized way. Explicit expressions can actually be said to be a set of information, while tacit knowledge, "implicit" or "tacit knowledge" is characterized by the fact that it cannot be formalized or explicitly formulated. It is a set of experiences, abilities, intuitions, personal ideas, and creative visions. It has a highly personal character that is hidden in the subconscious.

The approach of Japanese scientists is consistent with our concept: Ikujiro Nonaka and Hirotak Takeuchi inspired by Michael Polanyi and his tacit knowledge, hidden, unspoken knowledge, "attempted to understand knowledge and leadership as a synthesis process that could overcome - originally Western - in terms of the world in general and in research, in particular, through the search for a comprehensive harmony, integrity and concreteness within this "non-European", Asian, Japanese way of thinking.

\section{Conclusions}

Leadership and understanding, seen as a dynamic process, allow better use of creativity, making use of the success of, for example, Japanese companies in their business strategies.

There is also a rigorously perceived difference between explicit, unambiguously coded, and therefore through script, characters, language, communicative leadership on the one hand, and implied leadership that does not lay down on the one hand the emphasis on the system of knowledge, but on the way of obtaining it, which has its "dark faces", on the other.

And even metaphorical knowledge cannot be excluded from this process; it is not possible to tear science away from poetry [12].

\section{References}

[1] SELYE, H.: From Dreams to Discovery. McGraw-Hill, New York, 1964.

[2] Ambrozy et al. argue this point in their recent study. See: AMBROZY, M., VALCO, M., BHATTARAI, S.: The Ethical Aspect of Scientific Interest in Selected Physical Theories. Communications - Scientific Letters of the University of Zilina, 19(4), 79-84, 2017. For an inspiring hermeneutic of knowledge and existence see also: PETKOVSEK, R.: Memory as a Promise: a View from the Point of View of the Mimetic Theory and the Hermeneutics of Existence (in Slovenian). Bogoslovni Vestnik, 76(3/4), 495-508, 2016.

[3] ZEMAN, M.: Guide to the World's Literary Theory (in Czech). PANORAMA, Praha, 1988.

[4] In fact, as Valco and Sturak argue in their study on the 'relational self' of humans, "[h]uman contingency points us to a transcendent source of both, our being (ontologically) and existence as persons (phenomenologically, ethically - as selfaware, moral persons)", p. 293; italic mine. See: VALCO, M., STURAK, P.: The 'Relational Self': Philosophical-Religious Reflections in Anthropology 


\section{KOMNIKCCle}

and Personalism. XLinguae, 11(1XL), 289-299, 2018. On the topic of 'transcendent anthropology' see also: ZALEC, B.: On Not Knowing Who We Are: The Ethical Importance of Transcendent Anthropology. Synthesis Philosophica, 51(1), 105-115, 2011.

[5] SCHLESINGER, A. M.: Arthur M. Schlesinger, Jr. Quotes [online]. Brainyquote.com. Available: https://www.brainyquote.com/ quotes/authors/a/arthur_m_schlesinger_jr.html [accessed 2017-09-12].

[6] The topic of modern European literature, its origins as well as current intellectual potential, attracts high attention today. Among authors who are considered most inspiring are Don DeLillo and Soren A. Kierkegaard. In relation to Kierkegaard see: LISI, L. F.: Kierkegaard and Modern European Literature. The Oxford Handbook of Kierkegaard. Lippitt, J., Pattison, G. (Eds.), Oxford University Press, Oxford, 550-569, 2013; KRALIK, R., PAVLIKOVA, M.: The Reception of Kierkegaard's Work in Slovakia. Filozofia, 68(1), 82-86, 2013.

[7] PAVLIKOVA, M.: Kierkegaard's Reflection in Don DeLillo's Novel "Falling Man”. European Journal of Science and Theology, 13(1), 15-23, 2017. For a current research on the connection between the consumerist society and the power of media (especially in the lives of the so-called 'emerging adults') see: LESKOVA, A., VALCO, M.: Identity of Adolescents and its Dimensions in the Relation to Mass Media: Philosophical-Ethical Reflections (in Slovak). XLinguae, 10(3), 324-332, 2017.

[8] DEBNAR, M.: Between an Idea and an Image. Selected chapters from the philosophy of literature (in Slovak). Ars Poetica, Bratislava, 2013.

[9] RORTY, R.: Philosophical Orchids (in Slovak). Kaligram, Bratislava, 2006.

[10] BACHELARD, G.: Psychoanalysis of Fire (in Slovak). Smena, Bratislava, 1970.

[11] PLESNIK, L., et al.: Thesaurus of aesthetic expression qualities (in Slovak). Univerzita Konstantina Filozofa v Nitre, Nitra, 2008.

[12] HUNGERLAND, I. C.: Poetic Discourse. University of California Press, Berkeley and Los Angeles, 1958. 